\title{
The Implementation of TPR (Total Physical Response) Method in Teaching English for Early Childhood
}

\author{
Siti Sumihatul Ummah \\ STAIN Pamekasan, Jl. Raya Panglegur Km 4 Pamekasan, Indonesia \\ Corresponding e-mail: famixdefaru07@gmail.com
}

\begin{abstract}
TPR method is one of the appropriate method to be implemented in teaching English for early childhood. The teacher implemented TPR method in teaching English for students at RA. Nurul Hikmah Pamekasan. In this method, the teacher's role is as an order taker, a model provider, and an action monitor. Learners are as listeners and performers. They listen attentively and respond physically to the teacher's commands. The research purposes are to describe the implementation of TPR method in teaching English, to know parts of activities in the implementing of TPR method that make students become more interest and active to the English subject, and to know the students' response after learning English. The research method is qualitative descriptive. The data sources are from teacher and students. There are three ways to collect the data namely observation, interview, and documentation. The result of research showed that there were three steps in implementing TPR method namely pre-teaching, whilst-teaching, and post-teaching. Each steps has different activities. The teacher's role was as a model and an instructor. The students' role were as imitators because when the teacher acted out the imperative sentence to the students, they imitated the teacher's actions physically. Furthermore, at the first observation showed that the students were more active and interest in the whilst-teaching. At the second observation, they were more active and interest in the whilst and post-teaching. They became more active and interest to learn English because the teacher taught them by using imperative drilling and modelling concept that became the basic concept of TPR method. They exactly made them enjoyable and memorable in learning English. Finally, they did not only know and understand the material in the class but they also were able to practice it at their environment (out of the class).
\end{abstract}

Keywords: Implementation, TPR Method, Teaching English

\section{INTRODUCTION}

English is as an international language. In Indonesia, English has been applied for any levels. It has been applied from kindergarten up to college. It means that, English is not something new in our country. Many people use it to communicate each other in daily life. In fact, children also use it to communicate each other, to sing a song (kid songs), and to mention simple something such as numbers, colors, animals, etc. They use it like their first language although, sometime they use it by using bilingual. They are enough brave to practice it. Actually, they are still children but they are easy to memorize something that they ever see and listen it.

McLaughlin stated that childhood is golden age period, whereas their brain can save memory in the long term accurately (McLaughlin-1978). Learning
English for early childhood is so appropriate to be learned because their brain are still fresh, so the storage language process in their brain are pure, accurate, and so long. It can work in their brain effectively. In the kindergarten, Learning English for children under 6 years old to be done as the integrated language only. It is not a core subject. According to Christina that children, who are at $3-6$ years old, are faster to understand English if they often make interaction by using English in their daily life (Christina, 2010). So, Learning English in early childhood is the appropriate way to be done because we can teach English for them easily. They can understand the English subject easily by memorizing, imitating, modelling, and demonstrating based on the teacher' instruction. 
Teaching English for children are so different than other second language learners. It is also not easy job for the English teacher. The English teacher should know the ways, such as appropriate tricks and treats, to make the students interest and pay great attention to join with the English teaching learning process in the classroom. So, they can learn English happily. Besides that, Asrifan said that it is possible for the teachers to teach the young learners through fun activities (Asrifan, 2009). It means that, the English teacher should teach the students happily. Happy English learning for young learners as students is a learning English that create relax situation, fun, happy, and unfear for the students. Here, the English teacher should lost the students negative feeling in learning English, such as worry, shy, nervous, difficult, unconfident, scary, etc. The English teacher should show to the students that learning English is easy, fun, and happy. So, the students can interest to study it.

Furthermore, the kindergarten students at RA. Nurul Hikmah Pamekasan are still young learners. Their ages are about 5 up to 6 years old. It is the same with Rixon statement. He stated that the definition of young learner is children between the ages of about 5 up to 12 years old (Rixon, 1999). Teaching English for children, should be enjoyable, interesting, repetitive, and understandable. In this case, the English teacher should be creative in the English teaching learning process. The English teacher also should attend to the children development in using English as verbal communication. Scott and Lisbeth stated that the teacher role is so important in giving chances for them to use English as second language bravely (Scott and Lisbeth, 1992). That's way, there should be appropriate methods for teaching English to them. Hapidin said that one of successes the English teacher aspects in teaching English for children depends on how the teacher uses his/her teaching method (Hapidin, 2006).

One of the appropriate methods that was implemented by the English teacher at RA. Nurul Hikmah Pamekasan was TPR (Total Physical Response) method. It is one of the English teaching approaches and methods developed by Dr. James J Asher. It has been applied for almost thirty years. This method attempts to center attention to encouraging students to listen and respond to the spoken target language commands of their teacher. In other words, Larsen-Freeman stated that TPR is a language teaching method built around the coordination of speech and action. It also attempts to teach language through physical (motor) activity
(Larsen-Freeman, 1986). It tries to introduce some language skills or components in an action in which a teacher serves three roles. They are an order taker, a model provider, and an action monitor in which learners serve as models and action performers until they feel ready to speak out. Imperative drills are the prominent classroom activity in TPR.

In fact, most the kindergarten students at RA. Nurul Hikmah Pamekasan can communicate by using English in their daily life, although they are still early childhood. They mix between Indonesia and English sometime. But the most important thing is they used English like their first language, for example they often say "thank you mom" instead of terimakasih bu (Indonesian) to appreciate good action, "oh no..., you are wrong" instead of jangan..., kamu itu keliru (Indonesian) to blame someone else. For other examples such as "let's go together" instead of ayo kita pergi bersama (Indonesian) to ask their friends go to a certain place, "oh... it's so hot, open the window please...!" instead of oh...hawanya sangat panas, tolong bukakan pintunya (Indonesian) to ask someone to do something, and other examples that the writer does not mention one by one. They used English easily when they communicate with their friends or their teachers. Besides, they are also so brave to used it in their environment without shy and fear feelings.

From those examples, they are easy to imitate from what they saw, from what they listened, and from what they did, based on the English teacher's instruction because the English teacher at that school implemented TPR (Total Physical Response) method in the English teaching learning process. Whereas in this method, the English teacher is as a model and the students are as imitators. So that, the students imitate what the English teacher said. They also do what the English teacher instructed. These are few characteristics of TPR (Total Physical Response) method. Finally, they could use English as their second language easily.

Based on the phenomenon above, the researcher would like to know the implementation of TPR (Total Physical Response) method in the English teaching learning process for kindergarten students at RA. Nurul Hikmah Pamekasan. So that, the researcher would like to conduct a research with under title "The Implementation of TPR (Total Physical Response) Method in Learning English for Early Childhood at RA. Nurul Hikmah Pamekasan". Here, the researcher would like to know three aspects. The first, to know the implementation of TPR (Total Physical Response) method in the English teaching learning process for early 
childhood at RA. Nurul Hikmah Pamekasan. Second, to know parts of activities in the implementation of TPR (Total Physical Response) method that can motivate the students greatly to join with the English teaching learning process in the classroom. And the third, to know the students' responses after join with the English teaching learning process by implementing TPR (Total Physical Response) method at RA. Nurul Hikmah Pamekasan.

\section{RESEARCH METHOD}

This research is qualitative descriptive because the discussing of the problems will produce descriptive data and after that it will be presented in the report form. The data sources of this research are the English teacher and the students at RA. Nurul Hikmah Pamekasan. In this case, English has been taught only for the students who are at the B-1 class up to B-3 class because they can read and write. Their age was 6 years old or more than 6 years old but they were still under 7 seven years old. They have been at the same generation and they also had the same English capability. The researcher conducted this research at B-3 class which consist of 30 students. Here, there were 14 male students and 16 females' students.

Furthermore, the data collection procedure in this research was obtain by observation, interview, and a documentation. In observation, the researcher observed the English teaching learning process by implementing TPR (Total Physical Response) method for the students at RA. Nurul Hikmah Pamekasan. Here, the researcher was as a passive observer because the researcher only observed the English teaching learning process in the classroom without took a part to teach the students in the English teaching activities. She observe how the teacher taught English by implementing TPR method. She also saw the role of teacher and students in the English teaching learning process. She observed it by using observation-sheet. She conducted twice observation.

In interview, the researcher interviewed the English teacher and the students at B-3 class of RA. Nurul Hikmah Pamekasan. She interviewed the teacher first at the end of teaching activities. By doing this, she got information about the student's interest in joining the teaching activities. Here, she used unstructured interviewed type because she want to get the information as accurate as possible. Besides that, she also interviewed the students. She interviewed them in different day with the teacher because of limited time. She interviewed them in order to know the students response in learning English.

Finally, the resecher collect the data from documentation. The documentation of this research were obtain from observation guideline, documentation guideline, interview-sheet for English teacher, interview-sheet for the students, the students names list, and the photos of the English teaching learning process at the classroom.

\section{RESULT OF RESEACH}

\subsection{The Implementation of TPR (Total Physical Response) Method}

The researcher conducted observation twice. The first observation was on 08 May 2014 and the second observation was on 15 May 2014. The result of observation will be explained as follows:

\subsubsection{The first observation}

In the first observation, the English teacher provided three steps in teaching English for the students at RA. Nurul Hikmah Pamekasan. They are preteaching, whilst-teaching, post-teaching. Each of them has different activities. The English teacher taught the students by using bilingual. The researcher will explain as below:

$\begin{array}{ll}\text { Subject } & : \text { English } \\ \text { Topic } & : \text { Imperative (commands) } \\ \text { Method } & : \text { TPR } \\ \text { Class/Semester } & : \text { B-3/II } \\ \text { Day/Date/Month/Year } & : \text { Thusday/08 Mei } 2014 \\ \text { Time } & : 10.00\end{array}$

1. Pre-teaching

In pre-teaching, the English teacher did some teaching activities as follow:

a. The English teacher said greeting first to the students, for example:

Teacher : Good morning students?

Students : Good morning mom... (together)

Teacher : How are you?

Students : Fine... (together)

Teacher : Ok, thank you.

b. Before English subject was started, the English teacher asked the students to pray to the Lord together.

c. After that, the English teacher gave warming up to the students about the previous topic, for example:

Teacher : Are you ready to leran English now?

Students $\quad$ : Ok, yes... yes... yes... 
Teacher : Did you still remember class, what is the meaning of tangan (Indonesian) in Eglish? (the English teacher show her hands to the students)

Students : Hands... (together)

Teacher :Very good. Kalau bahasa inggrisnya "tepuk tangan"(Indonesian) itu apa ya? (the English teacher demonstrated clapping her hands to indicate the meaning of clapping)

Students : hmmm... (nobody knows)

Teacher : Ok, never mind if you forget. If you don't know the meaning of tepuk tangan (Indonesian). So, we learn together, ok.

Students : Ok, mom... (together)

Teacher : Apakah kalian ingin pintar berbahasa inggris? (Indonesian)

Students : Yes mom... (in chorous)

Teacher :Ok, sekarang ibu akan mengajarkan pada kalian tentang (Indonesian) imperative. Ada yang tau nggak, apa imperative itu?(Indonesian)

Students $\quad:$..... (nobody answer)

Teacher : Ok, today we will study about imperative.

d. The English teacher asked to the students to be silent and pay great attention to the material.

Based on the activities in the pre-teaching above, the researcher saw the interaction between teacher and students by using language mixing. It means that the teacher sometimes used mother tongue to explained the material to the students in order to the students were easiest to the teachers' instruction. The use of mother tongue by the teacher in the teaching English indicates one of the carachteristics of implementing TPR method. Beside that, the researcher also found out the teachers' role was as a model. The teacher demonstrated the action fisrt based on the topic, an after that the teacher ask to the students to imitate her action. By doing this, it made the students can be easy to predict it. It means that, the students were easiest to imitate than to memorize. Here, the researcher found the role of students were as imitators. It is also one of characteristic of TPR method. The researcher knows that from preteaching activities, the teacher implemented few of characteristics in TPR method.

\section{Whilst-teaching}

a. The English teacher started the English lesson by explaining about the topik (imperative).

b. The English teacher wrote down the topic on the whiteboard and complete with its meaning. Beside that, the English teacher also wrote down the examples of imperative on the whiteboard. In this case, there were six examples, such as bellow:

Stand up! : Berdiri (Indonesian)

Sit down! : : Duduk (Indonesian)

Jump! : Lompat (Indonesian)

Raise your hands! : Angkat tanganmu

(Indonesian)

Clap your hands! : Tepuk tanganmu (Indonesian)

Turn around! : berputar(Indonesian)

c. The English teacher asked to the students to sit in a circle.

d. The English teacher explained the meaning of each imperative and she also demonstrated these actions.

e. The English teacher asked to the students to imitate her in reading these imperative utterances rapidly.

f. The English teacher demonstrated again these imperative physically. In this case, she asked to the students to imitate her action based on their instruction. These activities were conducted by her rapidly in order to the students were able to understand what she instructed.

g. The English teacher gave chance to the students to practice it in front of the class in pairs.

h. The English teacher gave reward to the students who can reply the teacher' instruction correctly.

i. Finally, the English teacher asked to the students again practice it together with her by followed responses physically.

In whilst-teaching, the researcher found some characteristics and the principles of TPR method in the English teaching activities, such as

1. the English material was presented by the teacher in command form. according to richard theory the principle of this method consider the comprehension approach because the students must pay great attention to the teacher instructions. It comes from the students listening comprehension.

2. The spoken languge is emphasized over written language. It is one of characteristic of TPR method.

3. Vocabulary of imperatives above are also emphasized over other language areas. These are embedded within imperative.it is supported by Krashen and Terrell (1983) that the students listen to the teacher's instruction using target language communicatively. Then, the teacher help the students to understand her instruction by giving demonstration such as the examples of imperative utterances above. 


\section{Post-teaching}

a. The English teacher concluded the English lesson at the time by mentioning kinds of imperative.

b. The English teacher and students read kinds of imperative sentences together with their responses physically.

c. The English teacher motivated the students in order to study hard and practice it in teir daily life.

d. The English teacher close the meeting by closing.

In the post-teaching, the researcher found that the implementing of TPR method is pointed by the teacher and students read imperatives and performs together. It means that they read the imperatives first and after that they respond by using physical totally.

\subsubsection{The second observation}

The English teacher gave different topic but it was still in imperative context.

$\begin{array}{ll}\begin{array}{l}\text { Subject } \\ \text { Topic }\end{array} & \begin{array}{l}\text { : English } \\ \text { : Imperative (parts of } \\ \text { body) }\end{array} \\ \text { Method } & : \text { TPR } \\ \text { Class/Semester } & : \text { B-3/II } \\ \text { Day/Date/Month/Yea } & : \text { Thusday/15 Mei } 2014 \\ \text { Time } & : 10.00\end{array}$

\section{Pre-teaching}

In pre-teaching, the English teacher did some teaching activities as follow:

a. The English teacher said greeting first to the students. It was the same with the previous meeting.

b. Before English subject was started, the English teacher asked the students to pray to the Lord together.

c. The English teacher asked to the students to sing an English song together.

"Good morning"

Good morning, good morning, how are you?

Just fine

Good morning, good morning, how are you

just fine?

Good morning students,

Good morning teacher

Good morning, good morning, how are you just fine?

d. The English teacher gave brainstorming about the previous study, for example:

Teacher : What was the topic yesterday?

Students : Jump... jump... mom. (one of the students replying)

Teacher : Ok, very good. Others?
Students : forget mom. (few students replying)

Teacher : Well, yesterday we studied imperative. Dalam bahasa Indonesia artinya kalimat perintah (Indonesian). Siapa yang masih ingat apa bahasa inggrisnya

"berdiri"?(Indonesian)

Students : Stand up (in chorous)

Teacher : Excellent. How about melompat?(Indonesian)

Students : Jump (in chorous)

Teacher : Great... Now we learn about "parts of body". Who knows, what are they?

Students : head, hands, eyes, nose (students reply by various answers)

Teacher : Ok, thank you.

e. The English teacher asked to the students to be silent and pay great attention to the material.

Based on the result of second observation in preteaching, the reseacher saw the students were happy and enjoyable in learning English because at this section, the teacher stimulate the students first by sang a song with undertitle "good morning". The purpose is to make the students have great spirit and more focus on the English material.

\section{Whilst-teaching}

a. The English teacher started the English lesson by explaining a certain topic at the time.

b. The English teacher wrote down the certain topic "parts of body" on the whiteboard.

c. The English teacher put the pictures that indicate parts of body on the whiteboard.

d. The English teacher labeled them. Besides, she also wrote down the meaning of them in Indonesia in order to be understood easily by the students, for example:

$\begin{array}{lll}\text { - } & \text { Head } & \text { : kepala (Indonesian) } \\ \text { - } & \text { Eyes } & \text { : berdiri (Indonesian) } \\ \text { - } & \text { Nose } & \text { : duduk (Indonesian) } \\ \text { - } & \text { Mouth } & \text { : lompat (Indonesian) } \\ \text { - } & \text { Ears } & \text { : telinga (Indonesian) } \\ \text { - } & \text { Hands } & \text { : tangan (Indonesian) } \\ \text { - } & \text { Feet } & \text { : kaki (Indonesian) }\end{array}$

e. The English teacher asked to students to make a circle and she explained parts of body on the whiteboard.

f. The English teacher pointed and read parts of body one by one follewed by the students. Then, she translate them into Indonesia.

g. The English teacher show parts of body herself to the students by using English. Then, the students imitated together her action rapidly. 
h. The English teacher use the imperative sentences to indicate parts of body, for example:

$$
\begin{aligned}
& \text { - Touch your nose : sentuhlah hidungmu } \\
& \text { (Indonesian) } \\
& \text { - Point your head! : tunjuk kepalamu } \\
& \text { (Indonesian) }
\end{aligned}
$$

i. The English teacher demonstrated them by using imperative. Then, she asked to the students to imitate her action in introducing parts of body.

j. The English teacher mentioned parts of body in English and then the students are asked to response them physically. These activities were did by the English tearcher rapidly in order to be understood easly by the students.

k. The English teacher provided five group that consists of six students each group. Then, she examined the students to response physically based on her instruction.

1. The English teacher gave reward for the students in each group who could response correctly.

Actually, the whilst-teaching in the second observation is similar with the previous. But, it has different topic. Here, the implementation of TPR method appear when the teacher asked to the students to demonstrate English vocabulary about part of body by using imperative. Then, she asked to the students to imitate her action. It means that the teacher's role is as a model and the students' role are imitator. It is appropriate with the characteristic of TPR method.

\section{Post-teaching}

a. The English teacher concluded the English lesson "parts of body".

b. The English teacher and students read parts of body together with their meanings.

c. The English teacher motivated the students in order to study hard and practice it in teir daily life.

d. Before the English teacher close the meeting, she invited the studens to sang a song together with under title "if you happy".

Finally, the English teacher close the meeting by closing.

\subsection{Parts of Teaching English Activities That Can Motivate the Students Greatly}

Based on the result of observation, most of kindergarten students at RA. Nurul Hikmah Pamekasan more interest to learn English when the teacher asked them to practice the English lesson by giving responses physically because early childhood prefer to learn English with simple expressions, imitating, drilling, etc. In the context of teaching, most people assume that they learn a foreign language in the same way that they learn their mother tongue. Basically, they are potential in acquiring and learning a foreign language, and even they learn it more quickly than those who are learning the foreign language after puberty (McLaughlin, 1978). So, learning English for early childhood is not difficult exactly. However, the English teacher should be selective and creative in selecting the teaching method in order to they are still Great Spirit, happy, brave, enjoyable, and memorable the English lesson. Here are parts of teaching English activity that can motivate the students greatly such as below:

1. From the first observation

it was indicated that the students more motivate and antusius to join with English teaching process in the classroom at the whilst-teaching because in this section, the students looked like happy, enjoy, and more atractive to join with the subject. They tried to demonstrate the imperative utterances by using physical responses interchangeable. According to Linse (2005) that children prefer to learn foreign language by music and movement. This statement can support the result of research finding ata the first observation. In the whilst teaching, they did not stop to try imperative utterances by using fisically. In this case, they want to try and try again rapidly. They more interest if they were asked as a model in the classroom. They were also more confident when they could response to the teacher's instruction correctly. The researcher saw that they motivated to learn English greatly, for example in whilst-teaching, the teacher demonstrated an action of "jump" instead of melompat (Indonesian). So, the most students imatated to the teachers' action together by saying jump... jump... jump...! They said "jump" together happily. They looked like never felt tired and boring to practice it.

2. From the second observation 
For the second observation, the researcher found the students more interest to join with the English teaching learning process at whilst-teaching and post teaching. In whilst-teaching, the students great payed attention to the parts of body pictures. The teacher wrote the names of parts of body on the pictures. So that, the students were easy to understand them. It can help the students to memorize them fastly. In this case, the researcher saw that most students were active in the English teaching learning process. In fact, they had great motivation to response the teacher's instructions. They response it by louder voice. Furthermore, the students also motivated greatly to learn English at the post-teaching. In this phase, the students appeared atractive and active when the teacher asked them to sing a song together with under title "if you happy". The English song still related to the English lesson at the time. In fact, they were enjoy and great spirit to sing it. They still asked to the teacher to sing again although the time was over.

\subsection{The Students' Responses}

TPR (Total Physical Response) method has been appropriate to be implemented in the English teaching learning process for the kindergarten students at RA. Nurul Hikmah Pamekasan because they are early childhood. They prefer to learn English by imitating, memorizing, repeating, and demonstrating by using response physical totally. Teaching English for early childhood should be happy, interest, enjoy, fun, unbarring, understandable, and memorable for them. So, they can implement it easily in their daily life.

Based on the result of interview for the English teacher and the students at RA. Nurul Hikmah Pamekasan, the researcher knew about the students' responses after English teaching learning process by implementing TPR (Total Physical Response) method. Firstly, the researcher would like to explain the result of interview for the students. Generally, most students were interest, happy, and antusius when they joined with the English subject because they were still early childhood. According to Muhren (2003) that singing, imitating, demonstrating, and imperative drilling are the easy strategy to teach foreign language for early childhood. They could practice it directly in the classroom. They also felt easier to understand the English lesson explained by the teacher because the teacher gave clues to the students to try rapidly until they got the point. In addition, there were little students also did not great pay attention in English learning process because they prefer to play by himself or herself.

Secondly, the resercher known the students' responses from the English teacher interview at RA. Nurul Hikmah Pamekasan. It was obtained that the students usually felt borring and lazy in learning English if the English teacher was not creative and selective in choosing her English teaching method. Furthermore, in order to they can learn English happily, great spirit, unfear, unworry, and enjoy, so the English teacher can teach English by implementing TPR (Total Physical Response) method because in this method, the teachers are responsible for giving commands and monitoring actions taken by the learners. On the contrary, the learners are imitators of teachers verbal and nonverbal models. In teaching-learning process, the first phase is modeling. In this case, a teacher issues commands to learners, and performs the actions with them. In the second phase, learners demonstrate that they grasp the commands by performing them alone. The teacher monitors the learners actions. Above all, the interaction between a teacher and learners is signified by the teacher speaking and the learners res-ponding nonverbally. Later on, the learners become more verbal and the teacher responds nonverbally. In doing so, the students can be easier to remember the English lesson.

\section{CONCLUSIONS}

Based on the result of research, the researcher concludes that TPR (Total Physical Response) method was appropriate to be implemented in English teaching and learning process for the kindergarten students at RA. Nurul Hikmah Pamekasan. In teaching English activities, there were three phases in the English teaching and learning process. They are pre-teaching, whilstteaching, and post-teaching. Each of them has different activities. It depends on a certain topic that discussed by the teacher. In teaching English, the teacher also combined TPR (Total Physical Response) method with the English song in order to make the students interest to joint with the English teaching process in the classroom. So, they were not boring and lazy to learn it. In the first observation, the students more motivate and antusius to join with English teaching process in the classroom at the whilst-teaching. While the second observation, it appeared at the whilst-teaching and post-teaching. In this case, generally, most students were interest, happy, and antusius when they joined with the English teaching and learning process because they could practice it directly in the classroom. 


\section{REFERENCES}

Asrifan A. (2009). Using Songs in Teaching English Language for The Young Learners. PPS Umpar. Research Article. Pare-Pare: Univ. Muhammadiyah Pare-Pare.

Setiyadi B. A. (2006). Teaching English as Foreign Language. Yogyakarta: Graha Ilmu.

Christina N. W. (2010). English for Kindergarten Students. Jakarta. Talenta Media Utama.

Creswell J. W. (2012). Educational Research. Boston: Pearson Education.

Hapidin. (2006). Model-Model Pendidikan Untuk Anak Usia Dini. Jakarta: Ghiyats Alfiani Press.

Larsen-Freeman D. (1986). Techniques and Principles in Language Teaching. Oxford: Oxford University Press.

Linse, C. 2005. The Childrens Response: TPR and Beyond. English Teaching Forum 43/1: 8-11.

McLaughlin, B. 1978. Second Language Acquisition in Childhood. Boston:Allyn and Bacon.

Richards J. C., Theodore S. R. (2003). Approaches and Methods in Language Teaching. New York: Cambridge University Press.

Rixon, S. (1999). Young Learners of English: Some Research Perspectives. London: Longman.

Scott, W. A., Lisbeth H. Y. (1992). Teaching English to Children. London: Longman.

Suharsimi A. 2000. Manajemen Penelitian. Jakarta: PT. Rineka Cipta. 